\title{
KEY CHARACTERISTICS OF WOMEN AND MEN SUFFERING FROM ALCOHOL DEPENDENCE IN THE CONTEXT OF AUTO-AGRESSIVE BEHAVIOUR
}

\author{
O.Y. Somkina, A.V. Merinov, M.A. Baqkova \\ Ryazan State Medical University named after academician I.P. Pavlov, \\ Vysocovoltnaya str., 9, 390026, Ryazan, Russian Federation
}

Aim. To define the clinically and practically significant differences in characteristics of women and men who suffer from alcohol dependency in terms of auto-aggressive behavior associated with alcohol dependence. The article presents the analysis of data obtained in 124 subjects divided into two groups 62 subjects each, women and men suffering from alcohol dependence. Results. The study shows that women and men suffering from alcohol dependence have certain features throughout the course of the disease in the context of the auto-aggressive behavior. Most of the subjects were characterized by a hereditary development of the alcohol dependency represented by the presence of the alcoholism in mothers among $32 \%$ of female patients versus $10 \%$ among male ones. Women, in general, had more severe alcohol dependence ( $84 \%$ of the female subjects had rapid progression of the disease). The duration of therapeutic remission in most of the cases was less than a year, there were no prolonged therapeutic remissions ( 3 to 5 years).

Conclusion. Women and men have different course of the alcohol dependence, including the auto-aggressive behavioral characteristics, which in turn requires special attention of the medical services that provide narcological and anti-suicidal aid to both female and male patients. Development of gender-specific therapeutic approaches to the treatment of alcohol dependency is also required.

Keywords: alcohol dependence, auto-aggressive behavior, gender-specific alcohol addiction.

Alcohol abuse is a major problem for the modern society, it has negative medical and social consequences, and is also one of the most significant reasons of the lethal outcomes, increased incidence of the disease, and disability. The correlation between the average rate of alcohol ingestion per head and mortality rate among population is proved by the numerous studies. Approximately $17 \%$ of female mortality is due to alcohol dependence. The same parameter is higher among men, i.e. $-24 \%[1,2,3,4]$. The ratio between the men and women suffering from chronic alcoholism in developed European countries and the USA is now between $1: 5$ and $1: 2$, respectively, although earlier it was 1:12 and even less. Our country has had the constant ratios in the middle of the 1980-s: in 1991 it the ratio was 1:9 and its value increased up to 1:6 in 1995 . Nowadays the ratio is $1: 5$. American report that a 2:1 ratio in the USA $[5,6]$. But the analysis of the level of alcohol consumption among high school students in the USA hasn't shown notable gender distinctions. The similar results are presented by the Brazilian authors. The development of the female alcoholism is 
caused by the increasing affective disorders (depression, phobic anxiety etc.) [7, 8].

The crisis in economic and sociopsychological situation in the country has negative influence on youth, especially young girls and men, and is marked as a risk factor for the intensive increase in alcoholism rates. Alcohol dependence in adolescents has appeared as a result of emotive stress and personal disadaptation. Statistical analysis of the studies dedicated to the female and male alcoholism revealed certain discrepancies in data $[4,5,6]$. Although nowadays the relationship between alcoholism and suicidal conduct is well established, the major part of the published works were dedicated to men suffering from alcoholic dependence, while female alcoholism was considered an "inconvenient" and "non-delicate" topic for a discussion or research. There is no doubt that female suicide rates a lower as compared to male subject, however women tend to attempt suicide more often, which unfortunately sometimes has a success.

Thus, the aim of the study was to find out whether the men and women who suffer from alcoholic dependence have clinically and practically significant clinical differences for narcology and suicidology.

According to the fore mentioned aim, the objective of the study was to evaluate differences in characteristics of women and men in terms of auto-aggressive behavior associated with alcohol dependence which could make the treatment as much individual as possible in the aspect of the main narcological disease.

\section{Materials and methods}

Medical records from both public and private clinical practice were obtained for 62 women and 62 men who suffer from alcohol dependency (WSAD and MSAD, respectively). The diagnoses were set according to the International Statistical Classification of Diseases and Related Health Problems. All the examined patients had the second stage of the disease. Inclusion criterion was the presence of "alcoholic dependence". Accordingly, patients with the other types of dependences (except nicotine dependence), patients with endogenous mental diseases and structural diseases of the central nervous system, which occured before the development of the alcoholic dependence, were not included in the study. Another exclusion criterion was patient's refusal to give the agreement for the participation in the study. The average age of the subjects was 38.8 (4.3) years among women and 41.9 (4.3) among men. The family life in marriage was approximately 17.3 (6.6) among women and 17.4 (5.1) among men. The patients were comparable according to the socio-demographic factors. A "frontal" comparison of all the drug characteristics was performed in both groups. Statistical data processing was conducted using the guide on applied and medical statistics [9], data processing pack Microsoft Excel 2007, and Statistica 7.0. The statistical analysis has been completed in two stages. The prior stage included the analysis of the obtained data according to the type of distribution, and the descriptive statistical features of the extracts were also taken into account. The data adequacy according to the normal distribution was performed using the Pearson's chi-squared test $\left(\chi^{2}\right)$ and visual analysis of the similarity of the empiric and theoretical allocation with the use of the necessary histogram [9]. The statistical analysis of the data was performed using parametrical and non-parametrical methods of mathematic statistics (using the Student's and Wilcoxon's criteria). Descriptive statistics were used to describe the basic features of the data in the study.

\section{Results and discussion}

The statistically significant differences among female and male patients who suffer from alcoholic dependence are presented in the table 1 .

It was proven that hereditary predisposition to alcoholism from the paternal side played a major role in the development of alcohol dependence, up to two times more often than the one from maternal side. Hereditary predisposition 


\section{The statistically significant differences among female and male patients suffering from alcoholic dependence}

\begin{tabular}{|c|c|c|c|}
\hline \multicolumn{4}{|c|}{ Narcology parameters } \\
\hline Sign & Index of WSAD & Index of $M S A D$ & Value $p$ \\
\hline Hereditary predisposition to alcoholism from the maternal side & $32,26 \%$ & $9,68 \%$ & 0,0152 \\
\hline Rapid progression of the disease & $84 \%$ & $31 \%$ & 0,0001 \\
\hline Moderate progression of the disease & $16 \%$ & $55 \%$ & 0,0008 \\
\hline Amnestic disorders & $100 \%$ & $68 \%$ & 0,0004 \\
\hline Age of the alcohol abuse onset & $26,03(0,82)$ & $21,87(0,37)$ & 0,000001 \\
\hline Age of the abstinent syndrome onset & $28,84(0,83)$ & $24,61(0,37)$ & 0,000001 \\
\hline The abuse of "light" alcohol surrogates & $3 \%$ & $53 \%$ & 0,000001 \\
\hline The abuse of the "heavy" alcohol surrogates & $0 \%$ & $19 \%$ & 0,0216 \\
\hline Resuscitation required & $0 \%$ & $40 \%$ & 0,0001 \\
\hline The average duration of the alcohol consumption period (days) & $21,26(1,87)$ & $7,95(0,91)$ & 0,00001 \\
\hline The duration of the recent alcohol consumption period (days) & $21,58(2,05)$ & $8,66(1,12)$ & 0,000001 \\
\hline The remission period (days) & $87,16(10,30)$ & $48,06(4,32)$ & 0,000083 \\
\hline Tolerance(liters) & $0,87(0,06)$ & $1,14(0,06)$ & 0,004006 \\
\hline \multicolumn{4}{|c|}{ Treatment parameters } \\
\hline The duration of the therapeutic remission (days) & $195,32(19,25)$ & $153,82(31,12)$ & 0,007966 \\
\hline $\begin{array}{l}\text { Repeatedly treated (percent from the total number of the tested } \\
\text { patients) }\end{array}$ & $100 \%$ & $37 \%$ & 0,00001 \\
\hline
\end{tabular}

accounts to up to $100 \%$ cases of alcohol dependency in men. As shown on the table, the two groups have the statistically important differences according to maternal predisposition to alcoholism. As we can clearly see in the table 1 female patients were characterized by a rapid progression of the disease in $84 \%$ while there were no cases with slow progression of alcoholism dependency. More than half of the cases $(55 \%)$ of male alcoholism were characterized by a moderate progression of the disease. The patients in both groups were rather young at the onset of alcohol abuse and the development of the abstinent syndrome. A later onset of the disease (approximately 5 years) was observed among women, which corresponds to the literature data. [1,9]. Women developed the second stage of the disease including abstinent syndrome much faster than men do. At the same time women were less tolerant to "heavy drinking", had longer periods of remission. Although patients in both groups had a history of alcohol surrogates consumption, women had never used the so-called "heavy" surrogates (mordant, antifreeze etc.), which may explain the absence of the resuscitation procedures performed within this category of patients. Amnestic disorders were observed in $100 \%$ of female patients. The major part of them had victimized and paracriminal behavior.

Considering the treatment parameters, one can notice that no female patient had successful treatment in her medical record, which may be attributed to the rapid progression of the disease, longer alcohol consumption periods which are obvious, even marginal, with frequent suicide ideations. More than $1 / 3$ of women had undergone treatment three times or more. Only $37 \%$ of men who suffer from alcoholic dependence sought for medical help due to the "social acceptance" of alcoholism.

We observed that men and women had different course of the alcohol dependence, including the auto-aggressive behavioral characteristics, which in turn required special attention of the services that provide medical aid to both female and male patients.

\section{Conclusions}

1. Women who suffer from alcohol dependence had a worse course of the disease in terms of the personal auto-aggressive behavior compared to men. 
2. This was mainly attributed to the rapid progression of the disease and longer duration of the alcohol consumption period which was accompanied by frequent parasui-

\section{References}

1. Vasil'ev VV. Suicidal'noe povedenie zhenshhin (obzor literatury) [Suicidal behavior of women (rewiew)]. Suicidologija [Suicidology]. 2012; 1:18-28. (in Russian)

2. Zhukova JuA. Gendernye osobennosti autoagressivnogo spektra u stradajushhih alkogol'noj zavisimost'ju [Gender characteristics of aggressive behavior in people suffering from alcohol dependence]. Nauka molodyh (Eruditio Juvenium) [Science of young (Eruditio Juvenium)]. 2016; 2: 56-62. (in Russian)

3. Martynova AA. Vlijanie pola na autodestruktivnuju specifikaciju molodyh ljudej [Influence of gender on self-destructive specification young people]. Nauka molodyh (Eruditio Juvenium) [Science of young (Eruditio Juvenium)]. 2016; 2: 6267. (in Russian)

4. Merinov AV, Shitov EA, Lukashuk AV, Somkina OJu. Autoagressivnaja harakteristika zhenshhin, sostojashhih $\mathrm{v}$ brake $\mathrm{s}$ muzhchinami, stradajushhimi alkogolizmom [Autoagressive characteristic of women who are married to men who suffer from alcoholism]. Rossijskij mediko-biologicheskij vestnik imeni akademika I.P. Pavlova [I.P. Pavlov Russian Medical Biological Herald]. 2015; 4: 81-86. (in Russian)

5. Polozhij BS. Suicidalnoe povedenie (kliniko-ehpidemiologicheskie i ehtnokulturalnye aspekty) [Suicidal behavior (clinical, epi- cidial reactions.

3. Both female and male patients with alcohol dependency require gender-specific treatment options.

Authors declare no conflict of interest.

demiological and Ethnocultural Aspects)]. Moscow: RIO «FGU GNC SSP im. V.P. Serbskogo»; 2010. 232 p. (in Russian)

6. Rebrova OJu. Statisticheskij analiz medicinskih dannyh [Statistical analysis of medical data]. Moscow: Media Sfera; 2006. 312 p. (in Russian)

7. Lukashuk AV, Merinov AV. Klinikosuicidologicheskaja i jeksperi-mental'nopsihologicheskaja harakteristiki molodyh ljudej, vospi-tannyh v «alkogol'nyh» sem'jah [Clinical and a suicide and experimentally-psychological characteristics of young people brought up in the "alcoholic" families]. Nauka molodyh (Eruditio Juvenium) [Science of young (Eruditio Juvenium)]. 2014; 4: 82-87. (in Russian)

8. Merinov AV. Variant jepiskripta v sem'jah bol'nyh alkogol'noj zavisimost'ju [Option of episkript in families of patients with alcohol dependence]. Narkologija [Narcology]. 2010; 3: 77-80. (in Russian)

9. Shustov DI, Merinov AV. Diagnostika autoagressivnogo povedenija pri alkogolizme metodom terapevticheskogo interv'ju: posobie dlja vrachej psihiatrovnarkologov $i$ psihoterapevtov [Diagnosis of aggressive behavior in alcoholism by therapeutic interview: Handbook for psychiatrists and narcologists psychotherapists]. Ryazan; 2000. 20 p. (in Russian)

Somkina O.Y. - postgraduate, Psychiatry Department, Ryazan State Medical University named after academician I.P. Pavlov.

E-mail: Olyasomkina@gmail.com

Merinov A.V. - MD, Professor, Psychiatry Department, Ryazan State Medical University named after academician I.P. Pavlov.

E-mail: merinovalex@gmail.com

Baqkova M.A. - clinical resident, Psychiatry Department, Ryazan State Medical University named after academician I.P. Pavlov.

E-mail: lentazzz111@gmail.com 